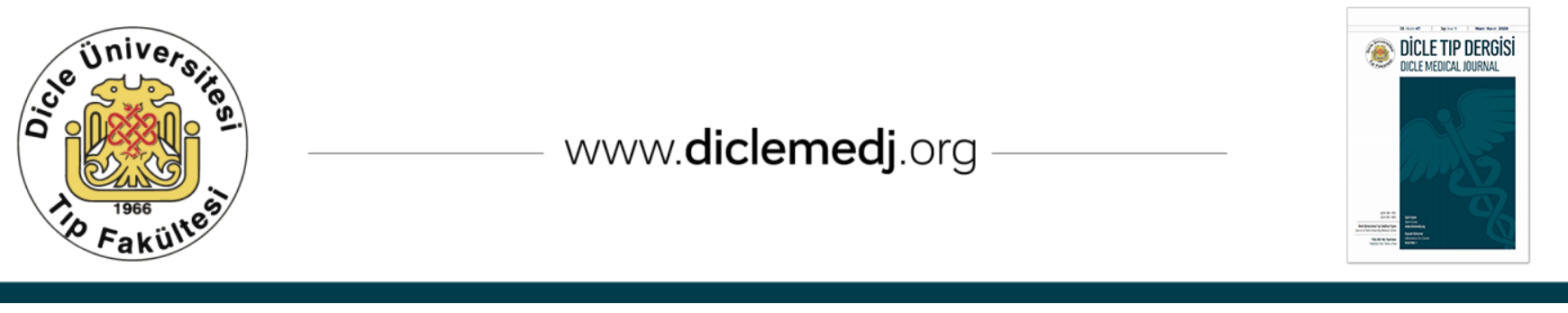

Original Article / Özgün Araştırma

\title{
Our Achalasia Surgery Experiences with the Achalasia Surgery Review
}

\author{
Tolga Kalayci ${ }^{1}$ iD, Ümit Haluk Iliklerden² ${ }^{2}$ \\ 1 Igdir State Hospital, Department of General Surgery, Igdir, Turkey \\ 2 Department of Surgery, School of Medicine, Van Yuzuncu Yil University, 65090, Van, Turkey
}

Received: 21.05.2019; Revised: 04.02.2020; Accepted: 11.02.2020

\begin{abstract}
Objective: Achalasia means disorder and dysfunction of Lower Esophageal Sphincter. Achalasia treatment was two types: non-surgical treatments and surgical treatments. Heller myotomy is the best surgical method of achalasia. In our study, we want to present our achalasia surgical experiences and the post-operative follow-up status of the patients for contribution to the literature.

Methods: After getting permission from ethics committee of our university, we collected data from patients who operated for achalasia between 2011 and 2019 retrospectively in Department of General Surgery, Van Yuzuncu Yil University Faculty of Medicine. Age and gender status, diagnosis process, presence of additional esophageal disease in the distal esophagus, surgical type, length of myotomy, presence of esophageal mucosal repair, duration of hospital stay and postoperative follow-up status of the patients were evaluated.
\end{abstract}

Findings: In our study, there were 11 patients who underwent achalasia surgery. The mean age of patients was 31.6 (1950) years. $63.63 \%(n=7)$ of all cases were female and $36.37 \%(n=4)$ were male. Apart from one case (case with hiatal hernia association) other cases were performed laparotomically. The mean myotomy length was calculated as 9.09 (815) $\mathrm{cm}$. The mean duration of hospital stay was 5.18 (3-7) days. Among the patients only one patient had difficulty in swallowing in the first month control. But it was observed that the same patient did not have difficulty in swallowing in the third month control.

Discussion: In our study, considering both our post-operative complication status and the patients' 1st and 3rd month controls; we saw that achalasia surgery was performed successfully in our clinic. An important deficiency is that laparoscopic surgery is not yet performed at our desired level in our clinic.

Keywords: Achalasia, Heller, Myotomy.

DOI: 10.5798/dicletip.705538

Correspondence / Yazışma Adresi: Tolga Kalayci, Igdir State Hospital, Department of General Surgery, Igdir, Turkey e-mail: dr.tolgakalayci@gmail.com 


\section{Akalazya Cerrahisi Derlemesi ile Akalazya Cerrahi Deneyimlerimiz}

\section{$\ddot{0} \mathbf{z}$}

Amaç: Akalazya, Alt Özofagus Sfinkterinin bozukluğu ve disfonksiyonu anlamına gelir. Akalazya tedavisi iki tiptir: cerrahi olmayan tedaviler ve cerrahi tedaviler. Heller miyotomi, akalazyanın en iyi cerrahi tedavi yöntemidir. Çalışmamızda, akalazya cerrahisi deneyimlerimizi ve hastaların ameliyat sonrası takip durumlarını literatüre katkıda bulunmak için sunmak istiyoruz.

Yöntemler: Üniversitemizin etik kurulundan izin aldıktan sonra, Van Yüzüncü Yıl Üniversitesi Tıp Fakültesi Genel Cerrahi Servisi'nde 2011-2019 yılları arasında akalazya nedeniyle opere edilen hastaların verilerini retrospektif olarak topladık. Hastaların yaş ve cinsiyet durumu, tanı süreci, distal özofagusta ek özofagus hastalığının varlığı, cerrahi tipi, myotomi uzunluğu, özofagus mukozal onarım varlığı, hastanede kalış süresi ve postoperatif takip durumu değerlendirildi.

Bulgular: Çalışmamızda akalazya ameliyatı geçiren 11 hasta vardı. Hastaların ortalama yaşı 31.6 (19-50) idi. Tüm olguların \%63,63'ü ( $\mathrm{n}=7$ ) kadın, \%36,37'si ( $\mathrm{n}=4$ ) erkekti. Bir olgu dışında (hiatal herni birlikteliği olan olgu) olgulara laparotomik cerrahi uygulandı. Ortalama miyotomi uzunluğu 9.09 (8-15) cm olarak hesaplandı. Ortalama hastanede kalış süresi 5.18 (3-7) gündü. Ameliyat geçiren hastalardan sadece birinde ilk ay kontrolünde yutma güçlügü görüldü. Fakat aynı hastanın üçüncü ay kontrolünde yutma güçlüğü olmadığı görülmüştür.

Tartışma: Çalışmamızda hem postoperatif komplikasyon durumumuzu hem de hastaların 1. ve 3. ay kontrollerini göz önünde bulundurarak; akalazya cerrahisinin kliniğimizde başarıyla uygulandığını gördük. Önemli bir eksiklik, kliniğimizde henüz laparoskopik cerrahinin istenilen düzeyde yapılmamasıdır.

Anahtar kelimeler: Akalazya, Heller, Myotomi.

\section{INTRODUCTION}

The meaning of achalasia is "non-relaxing". It mainly means disorder and dysfunction of Lower Esophageal Sphincter (LES) ${ }^{1,2}$.

Achalasia which can be idiopathic or infectious is a rare disease. Incidence of idiopathic achalasia is estimated to be 1:100.000. Achalasia due to infection of Trypanosoma Cruzi which is called as Chagas disease is a public health problem ${ }^{3}$.

Exact pathophysiology of achalasia is unknown. Multiple possible reasons can play role like infections, heredity or immunity.

Diagnosis of achalasia is based on history of patient. Most patients apply with paradoxically dysphagia, chest pain, and regurgitation. Additional investigations such as X-Ray Radiography, esophageal manometer and endoscopy are for validation diagnose.

Nowadays, there are lots of treatment of achalasia e.g. non-surgical methods like Botox,
Pneumatic dilation, Per-Oral Endoscopic Myotomy and surgical methods like Heller myotomy(laparotomic or laparoscopic).

In our study, we want to present our achalasia surgical experiences and the post-operative follow-up status of the patients for contribution to the literature.

\section{METHODS}

After getting permission from ethics committee of our university, we collected data from patients who operated for achalasia between 2011 and 2019 retrospectively in Department of General Surgery, Van Yuzuncu Yil University Faculty of Medicine.

Age and gender status, diagnosis process, presence of additional esophageal disease in the distal esophagus, surgical type, length of myotomy, presence of mucosal repair, duration of hospital stay and postoperative follow-up status (early period, 1st month control and 3rd month control) of the patients were evaluated. 


\section{RESULTS}

In our study, there were 11 patients who underwent achalasia surgery (Table I). The mean age of patients was 31.6 (19-50) years. $63.63 \%(n=7)$ of all cases were female and $36.37 \%(n=4)$ were male.

Table I: Data of All Patients.

\begin{tabular}{|c|c|c|c|c|c|c|c|c|}
\hline & G & Age & $\begin{array}{c}\text { Esophage } \\
\text { al } \\
\text { Patholog } \\
\text { y }\end{array}$ & $\begin{array}{l}\text { Surgery } \\
\text { Method }\end{array}$ & \begin{tabular}{|c} 
Myotom \\
$y$ \\
Length(c \\
m)
\end{tabular} & $\begin{array}{c}\text { Hospita } \\
1 \\
\text { Stay(Da } \\
\text { y) }\end{array}$ & $\begin{array}{c}1^{\text {st }} \\
\text { Month } \\
\text { Contr } \\
\text { ol }\end{array}$ & $\begin{array}{c}3^{\text {st }} \\
\text { Month } \\
\text { Control }\end{array}$ \\
\hline 1 & $\mathrm{~F}$ & 45 & Achalasia & HM & 9 & 6 & NP & NP \\
\hline 2 & $\mathrm{~F}$ & 50 & Achalasia & HM & 8 & 7 & $\begin{array}{c}\text { Difficul } \\
\text { ty In } \\
\text { Swallo } \\
\text { w }\end{array}$ & NP \\
\hline 3 & $\mathrm{~F}$ & 33 & Achalasia & HM & 9 & 6 & $\mathrm{NP}$ & $\mathrm{NP}$ \\
\hline 4 & $F$ & 27 & Achalasia & $\mathrm{HM}$ & 8 & 3 & NP & NP \\
\hline 5 & $\mathrm{~F}$ & 29 & $\begin{array}{c}\text { Achalasia } \\
+ \\
\text { Hiatal } \\
\text { Herni }\end{array}$ & $\begin{array}{l}\text { HM+Dor } \\
\text { Fundoplicat } \\
\text { ion } \\
\text { (Laparosko } \\
\text { pic) }\end{array}$ & $\mathrm{U}$ & 5 & NP & NP \\
\hline 6 & M & 25 & Achalasia & $\mathrm{HM}$ & 8 & 5 & NP & NP \\
\hline 7 & $\mathrm{M}$ & 37 & Achalasia & HM & 10 & 6 & NP & NP \\
\hline 8 & M & 24 & Achalasia & $\mathrm{HM}$ & 11 & 4 & NP & NP \\
\hline 9 & F & 19 & Achalasia & HM & 15 & 6 & NP & NP \\
\hline $\begin{array}{l}1 \\
0\end{array}$ & $\mathrm{~F}$ & 40 & Achalasia & HM & 12 & 5 & NP & NP \\
\hline $\begin{array}{l}1 \\
1\end{array}$ & $\mathrm{~F}$ & 19 & Achalasia & HM & 10 & 4 & NP & NP \\
\hline
\end{tabular}

G: Gender, F: Female, M: Male, U: Unspecified, NP: No Problem, Heller Myotomy: HM.

After evaluating the patient files retrospectively, we found that the diagnosis of achalasia was based on endoscopy and esophagus-stomach-duodenum graph in our cases. According to the data of our hospital, only 2 cases were diagnosed with endoscopy, 6 cases with endoscopy and esophagus-stomachduodenum radiograph combination. The preoperative examinations of three patients were performed by our surgeons according to the external center examinations that we could not find in the files.

While achalasia was present in 10 cases as primary pathology; only one case had achalasia concurrently with hiatal hernia. A combination of hiatal hernia and achalasia was performed laparoscopically Nissen fundoplication and Heller myotomy. The remaining cases were operated laparotomically Heller myotomy.

The mean myotomy length was calculated as $9.09(8-15) \mathrm{cm} .1$ patients were left out because the myotomy length was not specified in the operation note.

During myotomy, the esophageal mucosa was opened incidentally in 5 cases and the opening area was repaired with simple sutures.

The mean duration of hospital stay was 5.18 (37) days. All cases were discharged without complication. Among the patients only one patient had difficulty in swallowing in the first month control. But it was observed that the same patient did not have difficulty in swallowing in the third month control.

\section{DISCUSSION}

Achalasia was firstly described by Thomas Willis in 1674. It does not predominantly affect a particular age, race or gender 5 .

The mean age of achalasia was 62 years at study of Enestvedt et $\mathrm{al}^{6}$. On the other hand, O'Neill impressed a bimodal distribution for achalasia by age, with peaks at around age 30 and 60 years $^{7,9}$.

Castell showed that achalasia affects both sexes equally and there are two peaks of incidence: the first in the 3rd to 4th decades and a second after 60 years of age ${ }^{10}$. At study of Duffield et al, the mean age at diagnosis was 62.111.

In adults, achalasia occurs with equal frequency in men and women ${ }^{12,13}$ and in white and nonwhite people ${ }^{6}$, but incidence increases with age. 
In most studies, the mean age at diagnosis was over 50 years ${ }^{12,14}$.

In our study, the mean age was 31.6 (19-50) years and suitable for first peak of bimodal distribution of achalasia. Opposite of literature studies, the majority gender is female gender (7 vs. 4).

From past to present, achalasia treatment has chanced depending on new methods. There are two types of treatment methods accepted today: non-surgical treatments and surgical treatments. At non-surgical treatments; medical agents (like calcium channel blockers or nitrates or botulinium toxin injection) or endoscopic balloon dilatation or POEM (Per Oral Endoscopic Myotomy) are mostly used methods for achalasia treatment.

At surgery techniques; everything was started with Heller myotomy. Heller was firstly described cardiomyotomy for achalasia surgery at 1914. Over the years, open Heller myotomy has been replaced by closed myotomy. Today, Heller myotomy is seen as the gold standard method for achalasia surgery; It is debated whether an anti-reflux procedure will be added to Heller myotomy. Nowadays, the general opinion of achalasia surgery is that laparoscopic Heller myotomy with partial fundoplication ${ }^{15}$.

Another point we want to emphasize is whether there is an accepted myotomy. In the literature, recommended myotomy area is nearly 4 to $8 \mathrm{~cm}$ proximal of gastro esophageal junction (GEJ) and 0.5 to $2 \mathrm{~cm}$ distal of $\mathrm{GEJ}{ }^{16}$, which has been associated to lower dysphagia rates and LES resting pressures. Oelschlager et al. have shown that when the distal myotomy in the stomach was increased to $3 \mathrm{~cm}$, patients were not worry about dysphagia, pyrosis or regurgitation ${ }^{17}$. Unfortunately, there was no study about comparison of short and long myotomy. Therefore there was no precise information ${ }^{18,19}$. Nevertheless, a longer myotomy may be more appropriate to prevent dysphagia ${ }^{20}$. In our study, the mean length of myotomy was 9.09 (815) $\mathrm{cm}$ and it was compatible with the literature.

Also, we want to impress which method is the best for treatment of achalasia. Nowadays, laparoscopic surgery is the best. But there is no common thought about which laparoscopic method is the best? Although there was a trend toward minimally invasive operations for Heller myotomy, the value of adding a fundoplication was still uncertain.

Several authors believed that it Heller myotomy with anti-reflux procedure would cause recurrence of dysphasia due to lack of peristalsis ${ }^{21}$.

Topart et $\mathrm{al}^{22}$ found at a 10 -year follow-up after laparoscopic Heller myotomy with Nissen fundoplication that most of the patients (82\%) have recurrence of symptoms, whereas Rossetti et $\mathrm{al}^{23}$ described excellent dysphagia alleviation in $>90 \%$ of patients, and no GER at mean followup of 83 months.

Di Martino et al $^{24}$ compared anterior and posterior fundoplication after laparoscopic Heller myotomy. They reported similar GER and dysphagia symptom scores.

Rebecchi et al compared Dor (72 case) fundoplication and Nissen (72 case) fundoplication at Heller myotomy. The incidence of GER was low and similar but dysphagia was higher after Nissen compared with only $2.8 \%$ after Dor fundoplication 25 .

In our study, considering both our postoperative complication status and the patients' 1st and 3rd month controls; we saw that achalasia surgery was performed successfully in our clinic. In conclusion, an important deficiency is that laparoscopic surgery is not yet performed at our desired level in our clinic. Increasing our laparoscopic case experiences; we must complete the surgical learning curve and compare our open and closed surgical experiences as soon as possible. 
Ethics Committee Approval: After getting permission from ethics committee of our university, we collected data from patients who operated for achalasia between 2011 and 2019 retrospectively in Department of General Surgery, Van Yuzuncu Yil University Faculty of Medicine.

Conflicts of interest: The authors have no conflict of interests to declare.

Financial Disclosure: The authors declared that this study has received no financial support.

\section{REFERENCES}

1. Lindman BR, Clavel M-A, Mathieu P, et al. Calcific aortic stenosis. Nat Rev Dis Prim. 2016; 2: 16006.

2. Eveborn GW, Schirmer H, Heggelund G, et al. The evolving epidemiology of valvular aortic stenosis. the Tromsø Study. Heart. 2013 Mar 15; 99: 396-400.

3. Nishimura RA, Otto CM, Bonow RO, et al. 2014 AHA/ACC guideline for the management of patients with valvular heart disease: a report of the American College of Cardiology/American Heart Association Task Force on Practice Guidelines. J Am Coll Cardiol. 2014 Jun 10; 63: e57-185.

4. Bagur R, Webb JG, Nietlispach F, et al. Acute kidney injury following transcatheter aortic valve implantation: predictive factors, prognostic value, and comparison with surgical aortic valve replacement. Eur Heart J. 2010 Apr 1; 31: 865-74.

5. Najjar M, Salna M, George I. Acute kidney injury after aortic valve replacement: Incidence, risk factors and outcomes. Expert Review of Cardiovascular Therapy. 2015.

6. Papa A, Emdin M, Passino C, et al. Predictive value of elevated neutrophil-lymphocyte ratio on cardiac mortality in patients with stable coronary artery disease. Clin Chim Acta. 2008 Sep; 395: 27-31.

7. Park B-J, Shim J-Y, Lee H-R, et al. Relationship of neutrophil-lymphocyte ratio with arterial stiffness and coronary calcium score. Clin Chim Acta. 2011 May 12; 412: 925-9.

8. Zazula AD, Précoma-Neto D, Gomes AM, et al. An assessment of neutrophils/lymphocytes ratio in patients suspected of acute coronary syndrome. Arq Bras Cardiol. 2008 Jan; 90: 31-6.

9. Duffy BK, Gurm HS, Rajagopal V, et al. Usefulness of an Elevated Neutrophil to Lymphocyte Ratio in Predicting Long-Term Mortality After Percutaneous Coronary Intervention. Am J Cardiol. 2006 Apr 1; 97: 9936.

10. Gibson PH, Cuthbertson BH, Croal BL, et al. Usefulness of Neutrophil/Lymphocyte Ratio As Predictor of New-Onset Atrial Fibrillation After Coronary Artery Bypass Grafting. Am J Cardiol. 2010 Jan 15; 105: 186-91.

11. Rudiger A, Burckhardt OA, Harpes $P$, et al. The relative lymphocyte count on hospital admission is a risk factor for long-term mortality in patients with acute heart failure. Am J Emerg Med. 2006 Jul; 24: 451-4.

12. Gibson PH, Croal BL, Cuthbertson BH, et al. Preoperative neutrophil-lymphocyte ratio and outcome from coronary artery bypass grafting. Am Heart J. 2007 Nov; 154: 995-1002.

13. Bhat T, Teli S, Rijal J, et al. Neutrophil to lymphocyte ratio and cardiovascular diseases: a review. Expert Rev Cardiovasc Ther. 2013 Jan 10; $11: 55-9$.

14. Kappetein AP, Head SJ, Généreux P, et al. Updated standardized endpoint definitions for transcatheter aortic valve implantation: the 
Valve Academic Research Consortium-2 consensus document†. Eur Heart J. 2012 Oct; 33: 2403-18.

15. Roques F, Michel P, Goldstone AR, et al. The logistic EuroSCORE. Eur Heart J. 2003 May 1; 24: 882-3.

16. Park JJ, Jang HJ, Oh IY, et al. Prognostic value of neutrophil to lymphocyte ratio in patients presenting with ST-elevation myocardial infarction undergoing primary percutaneous coronary intervention. Am J Cardiol. 2013;

17. Bhat T, Teli S, Rijal J, et al. Neutrophil to lymphocyte ratio and cardiovascular diseases: A review. Expert Review of Cardiovascular Therapy. 2013.

18. Onuk T, Güngör B, Karataş B, et al. Increased neutrophil to lymphocyte ratio is associated with in-hospital mortality in patients with aortic dissection. Clin Lab. 2015; 61.

19. Yin $Y$, Wang J, Wang X, et al. Prognostic value of the neutrophil to lymphocyte ratio in lung cancer: A meta-analysis. Clinics. 2015;

20. Turkmen K, Guney I, Yerlikaya FH, et al. The relationship between neutrophil-to-lymphocyte ratio and inflammation in end-stage renal disease patients. Ren Fail. 2012; 34: 155-9.

21. Erdem E. Neutrophil lymphocyte ratio in aute renal failure. Indian J Nephrol. 2015; 25: 126-7.
22. Mozos I, Malainer C, Horbańczuk J, et al. Inflammatory Markers for Arterial Stiffness in Cardiovascular Diseases. Front Immunol. 2017 Aug 31; 8: 1058.

23. Li J, Chen $Q$, Luo $X$, et al. Neutrophil-toLymphocyte Ratio Positively Correlates to Age in Healthy Population. J Clin Lab Anal. 2015 Nov; 29: 437-43.

24. Nam S-H, Kang S-G, Song S-W. The Neutrophil-Lymphocyte Ratio Is Associated with Coronary Artery Calcification in Asymptomatic Korean Males: A Cross-Sectional Study. Biomed Res Int. 2017 Feb 9; 2017: 1-8.

25. Candela P, Evola S, Lunetta M, et al. The spectrum of risk factors for contrast induced nephropathy in patients undergoing coronary angiography or intervention. J Indian Coll Cardiol. 2014 Sep 1; 4: 157-61.

26. Gürsoy OM, Karakoyun S, Kalçılk M, et al. Usefulness of Novel Hematologic Inflammatory Parameters to Predict Prosthetic Mitral Valve Thrombosis. Am J Cardiol. 2014 Mar; 113: 8604.

27. Ram P, Mezue K, Pressman G, et al. Acute kidney injury post-transcatheter aortic valve replacement. Clin Cardiol. 2017 Dec 1; 40: 135762. 